\title{
PVP-stabilized tungsten oxide nanoparticles inhibit proliferation of NCTC L929 mouse fibroblasts via induction of intracellular oxidative stress
}

\author{
A. L. Popov ${ }^{1}$, A. M. Ermakov ${ }^{1}$, T. O. Shekunova ${ }^{2,4}$, A. B. Shcherbakov ${ }^{3}$, O. N. Ermakova ${ }^{1}$, O. S. Ivanova ${ }^{4}$, \\ N. R. Popova ${ }^{1}$, A. Ye. Baranchikov ${ }^{4}$, V. K. Ivanov ${ }^{4, *}$ \\ ${ }^{1}$ Institute of Theoretical and Experimental Biophysics, Russian Academy of Sciences, \\ Pushchino, Moscow region, 142290, Russia \\ ${ }^{2}$ Lomonosov Moscow State University, Moscow, 119991, Russia \\ ${ }^{3}$ Zabolotny Institute of Microbiology and Virology, National Academy of Sciences of Ukraine, \\ Kyiv, D0368, Ukraine \\ ${ }^{4}$ Kurnakov Institute of General and Inorganic Chemistry, Russian Academy of Sciences, Moscow, 119991, Russia \\ antonpopovleonid@gmail.com, ao_ermakovy@rambler.ru, taisia.shekunova@yandex.ru, carotene@igic.ras.ru, \\ beoluchi@yandex.ru,runetta05@mail.ru,nellipopovaran@gmail.com, a.baranchikov@yandex.ru, *van@igic.ras.ru
}

PACS 68.65.k, 81.20.n, 82.70.Dd, 82.50.Hp, 87.17.Ee

DOI 10.17586/2220-8054-2019-10-1-92-101

\begin{abstract}
In this study, photochromic PVP-stabilized tungsten oxide nanoparticles ( $\mathrm{WO}_{3-x} \mathrm{NPs}$ ) were shown to exhibit a dose-dependent cytotoxic effect on mouse fibroblasts in vitro. $\mathrm{WO}_{3-x}$ NPs reduce viability and proliferative activity of the cells via induction of intracellular oxidative stress leading to apoptosis and cell death. $\mathrm{WO}_{3-x}$ NPs modulate the mRNA expression of a wide range of genes responsible for oxidative stress and the cell redox-system.
\end{abstract}

Keywords: tungsten oxide nanoparticles, cytotoxicity, apoptosis, fibroblasts.

Received: 3 January 2019

Revised: 22 January 2019

\section{Introduction}

Metal oxide-based nanomaterials are widely used in biomedical applications as radioprotectors, radiosensitizers, photosensitizers, contrast agents, etc. One of the most promising X-ray contrast agents is nanocrystalline tungsten oxide $\left(\mathrm{WO}_{3-x}\right)$ [1-5]. In recent years, $\mathrm{WO}_{3-x}$ NPs have also been widely employed in antibacterial coatings or biosensors [6,7]. Due to the specific physical and chemical properties of $\mathrm{WO}_{3-x} \mathrm{NPs}$, such as high surface energy and surface-to-volume ratio, quantum confinement effects and local plasmon resonance effects, they can be used in photothermal cancer therapy [8,9]. Sharker et al. synthesized dopamine-conjugated hyaluronic acidcoated WO3 nanoparticles ( $\mathrm{WO}_{3}-\mathrm{HA}$ ) which demonstrated quite efficient photothermal conversion with timedependent tumor-specific accumulation [10]. Zhou et al. used tungsten oxide nanorods for effective photothermal

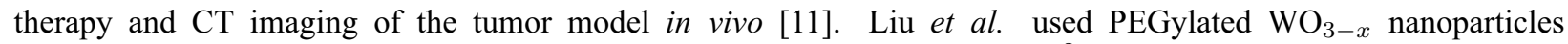

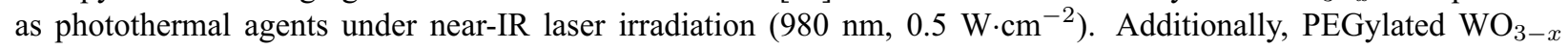
nanoparticles were shown to be effective CT imaging contrast agent on a tumor-bearing mouse model [12]. Liu et al. used ultrasmall $\mathrm{WO}_{3-x} @ \gamma$-poly-L-glutamic acid $\left(\mathrm{WO}_{3-x} @ \gamma-\mathrm{PGA}\right)$ nanoparticles with good photoacoustic and photothermal properties for effective photothermal-enhanced chemodynamic therapy [13]. AbuMousa demonstrated enhancement of photocatalytic activity of nanostructured silver loaded tungsten oxide providing high anticancer efficiency under UV radiation [14].

The usage of tungsten oxide in advanced therapeutic compositions requires an in-depth systematic study of their cytotoxicity including detailed investigation of molecular mechanisms of $\mathrm{WO}_{3-x} \mathrm{NPs}$ action on mammalian cells. Here, we analyzed the cytotoxicity of PVP-stabilized $\mathrm{WO}_{3-x}$ nanoparticles using the mouse fibroblasts NCTC L929 cell line and provided the first report on the molecular mechanisms of $\mathrm{WO}_{3-x}$ nanoparticles' cytotoxic action.

\section{Materials and methods}

\subsection{Synthesis and characterization of tungsten oxide nanoparticles}

Ultrasmall hydrated tungsten oxide nanoparticles were synthesized by hydrothermal processing of tungstic acid in the presence of polyvinylpyrrolidone (PVP K-30, average mol. wt. 40,000) acting as template, stabilizer and growth regulator. Tungstic acid was prepared by ion-exchange method using sodium tungstate $\left(\mathrm{Na}_{2} \mathrm{WO}_{4}\right)$ solution and strongly acidic cation exchange resin (Amberlite $\mathbb{R}$ IR120). Briefly, ion exchange resin (in hydrogen form) 
was swelled in water and loaded into the glass column (filling volume $200 \mathrm{ml}$ ). Then, $100 \mathrm{ml}$ of $0.05 \mathrm{M}$ sodium tungstate solution was passed through the column dropwise, $4 \mathrm{~g}$ of PVP was added to the obtained eluent; the solution was transferred to the flask and stirred for $4 \mathrm{~h}$ under reflux. During heating a clear sol of hydrated $\mathrm{WO}_{3-x}$ was formed, as shown by the appearance of UV-absorption band at $325 \mathrm{~nm}$ and Tyndall cone observation. For cytotoxicity study, $\mathrm{WO}_{3-x}$ sol was diluted to prepare $0.1-25.0 \mathrm{mg} / \mathrm{ml}$ colloid solutions.

Comprehensive analysis of $\mathrm{WO}_{3-x}$ nanoparticles was performed as described elsewhere [15].

\subsection{Investigation of $\mathrm{WO}_{3-x}$ photochromic properties}

To analyze the photochromic properties of the PVP-stabilized $\mathrm{WO}_{3-x}$ sol, it was subjected to UV exposure (BLX-E312 chamber) for $10 \mathrm{~min}$ : then the absorption spectra of the irradiated sol were analyzed using an OceanOptics QE65000 spectrometer for every 10 seconds during $10 \mathrm{~min}$. After that, the sample was subjected to UV exposure for the second time. Such procedure (cycle) was repeated 10 times. The volume of the sol was $2 \mathrm{ml}$, the sol was diluted by 50 fold, i.e. the $\mathrm{WO}_{3-x}$ concentration was about $0.0006 \mathrm{M}$. The temperature of the cuvette compartment was maintained at $37^{\circ} \mathrm{C}$.

\subsection{Cell culture}

In vitro experiments were performed using a mouse fibroblast NTCT L929 cell line. The cells were cultivated in a DMEM/F12 (1:1) medium containing $10 \%$ of fetal bovine serum (FBS), $50 \mu \mathrm{g} / \mathrm{mL}$ of penicillin, $50 \mu \mathrm{g} / \mathrm{mL}$ of streptomycin and $1 \%$ of L-glutamine. The cells were cultivated at $37{ }^{\circ} \mathrm{C}$ in a humid atmosphere containing $95 \%$ air and $5 \% \mathrm{CO}_{2}$. The cells were seeded with the density of $30,000-35,000$ per $\mathrm{cm}^{2}$. Fetal bovine serum (FBS), penicillin, streptomycin, Dulbecco's Modified Eagle Medium (DMEM), F12 medium, L-glutamine, trypsin/versene solution were purchased from PanEco and Biosintez, Russia. Six hours after cells attachment, the medium was replaced by a medium containing different concentrations of $\mathrm{WO}_{3-x}$ NPs. In the control experiments, the cells were cultured without $\mathrm{WO}_{3-x}$ NPs.

\subsection{MTT assay}

Determination of mitochondrial and cytoplasmic dehydrogenase activity in living cells was performed using the MTT assay, which is based on the reduction of a colorless tetrazolium salt (3-citation[4,5-dimethylthiazol-2-yl]2,5-diphenyltetrazolium bromide, MTT). 24, 48 and $72 \mathrm{~h}$ after cell incubation with $\mathrm{WO}_{3-x}$ NPs a standard MTT assay was performed.

\subsection{Analysis of proliferative activity}

Cells were seeded in 24 well plates. After incubation for 6 hours, $\mathrm{WO}_{3-x}$ NPs were added to the cells at various concentrations $(1-15 \mathrm{mg} / \mathrm{ml})$. After 24, 48 and 72 hours cells were counted using Clone Select Imager (Molecular Device, USA).

\subsection{Live/Dead viability assay}

To evaluate the cytotoxic effects of the $\mathrm{WO}_{3-x} \mathrm{NPs}$, a Live/Dead Viability Kit (Invitrogen, Life Technologies) was used. Cells attached to the 96-well plate were processed according to the manufacturer's protocol, and visualized 25 minutes after adding the dye with an Axiovert 200 fluorescence-light microscope (Carl Zeiss, Germany) and recorded by a Canon A620 digital camera (Canon, USA). The green signal (SYTO $9 \lambda=485 / 498 \mathrm{~nm}$ ) characterized live cells and the red signal (propidium iodide $\lambda=535 / 617 \mathrm{~nm}$ ) characterized dead cells. For each cell group, four fields in each well were examined.

\subsection{PCR-RT}

In order to extract mRNAs a kit with magnetic particles was used, according to the manufacturer's protocol (Sileks, Russia). Reverse transcription was performed by a Sileks kit (Russia) using oligodT primer according to the manufacturers protocol. The produced cDNAs served as a real-time PCR matrix. The amplification was performed on a CFX-96 amplifier (BioRad, USA) or an ABI 7500 Fast Real-Time PCR System (Applied Biosystems, USA). We determined the expression of 96 genes responsible for key cell processes (Table 1). 
TABLE 1. Selected gene groups for PCR-RT analysis

\begin{tabular}{|c|c|c|c|}
\hline Description & Symbol & Description & Symbol \\
\hline glutathione peroxidase 1 & Gpx1 & interleukin 22 & $I l 22$ \\
\hline glutathione peroxidase 2 & Gpx2 & $\begin{array}{l}\text { alsin Rho guanine nucleotide exchange } \\
\text { factor }\end{array}$ & Als2 \\
\hline glutathione peroxidase 3 & Gpx3 & apolipoprotein E & Apoe \\
\hline glutathione peroxidase 4 & Gpx4 & chemokine (C-C motif) & Ccl5 \\
\hline glutathione peroxidase 5 & Gpx5 & $\begin{array}{l}\text { excision repair cross-complementing } \\
\text { rodent repair deficiency complementa- } \\
\text { tion group } 2\end{array}$ & $\operatorname{Ercc2}$ \\
\hline glutathione peroxidase 6 & Gpx6 & $\begin{array}{l}\text { excision repair cross-complementing } \\
\text { rodent repair deficiency, complementa- } \\
\text { tion group } 6\end{array}$ & Ercc6 \\
\hline glutathione peroxidase 7 & Gpx7 & ferritin heavy polypeptide 1 & Fth1 \\
\hline $\begin{array}{ll}\text { glutathione } & \text { S-transferase } \\
\text { kappa 1 } & \end{array}$ & Gstk1 & $\begin{array}{l}\text { glutamate-cysteine ligase, catalytic } \\
\text { subunit }\end{array}$ & Gclc \\
\hline $\begin{array}{l}\text { glutathione S-transferase, } \\
\text { pi } 1\end{array}$ & Gstp1 & $\begin{array}{l}\begin{array}{l}\text { glutamate-cysteine ligase, modifier } \\
\text { subunit }\end{array} \\
\text { lat }\end{array}$ & Gclm \\
\hline EH-domain containing 2 & Ehd2 & glutathione synthetase & Gss \\
\hline peroxiredoxin 1 & $\operatorname{Prdx1}$ & heme oxygenase 1 & Hmoxl \\
\hline peroxiredoxin 2 & $\operatorname{Prdx2}$ & $\begin{array}{l}\text { heat shock protein } 90 \text { alpha (cytosolic), } \\
\text { class B member } 1\end{array}$ & Hspala \\
\hline peroxiredoxin 3 & $\operatorname{Prdx} 3$ & $\begin{array}{l}\text { isocitrate dehydrogenase } 1(\mathrm{NADP}+) \text {, } \\
\text { soluble }\end{array}$ & Idh1 \\
\hline peroxiredoxin 4 & $\operatorname{Prdx} 4$ & keratin 1 & Krt1, \\
\hline peroxiredoxin 5 & $\operatorname{Prdx} 5$ & myeloperoxidase & Mpo \\
\hline peroxiredoxin 6 & $\operatorname{Prdx6}$ & $\mathrm{NAD}(\mathrm{P}) \mathrm{H}$ dehydrogenase, quinone 1 & Nqo1 \\
\hline $\begin{array}{l}\text { adenomatosis polyposis } \\
\text { coli }\end{array}$ & $A p c$ & $\begin{array}{l}\text { Parkinson disease (autosomal reces- } \\
\text { sive, early onset) } 7\end{array}$ & Park7 \\
\hline catalase & Cat & prion protein & Prnp \\
\hline cathepsin B & Ctsb & $\begin{array}{l}\text { proteasome (prosome, macropain) sub- } \\
\text { unit, beta type } 5\end{array}$ & Psmb5 \\
\hline dual oxidase 1 & Duoxl & sequestosome 1 & Sqstm1 \\
\hline eosinophil peroxidase & Epx & thioredoxin 1 & Txn1 \\
\hline lactoperoxidase & Lpo & thioredoxin interacting protein & Txnip \\
\hline myeloperoxidase & Mpo & $\begin{array}{l}\text { uncoupling protein } 3 \text { (mitochondrial, } \\
\text { proton carrier) }\end{array}$ & Ucp3 \\
\hline $\begin{array}{l}\text { prostaglandin- } \\
\text { endoperoxide synthase } \\
1\end{array}$ & Ptgs 1 & $\begin{array}{l}\text { xeroderma pigmentosum, complemen- } \\
\text { tation group A }\end{array}$ & $X p a$ \\
\hline $\begin{array}{l}\text { prostaglandin- } \\
\text { endoperoxide synthase } \\
2\end{array}$ & $\operatorname{Ptgs} 2$ & ataxia telangiectasia and $\operatorname{Rad} 3$ related & Atr \\
\hline $\begin{array}{l}\text { recombination activating } \\
\text { gene } 2\end{array}$ & Rag2 & cytoglobin & Cygb \\
\hline
\end{tabular}




\begin{tabular}{|c|c|c|c|}
\hline $\begin{array}{l}\text { erine (or cysteine) pepti- } \\
\text { dase inhibitor, clade B, } \\
\text { member } 1 b\end{array}$ & Serpinb1b & dynamin 2 & Dnm2 \\
\hline thyroid peroxidase & Tpo & $\begin{array}{l}\text { Fanconi anemia, complementation } \\
\text { group C }\end{array}$ & Fancc \\
\hline albumin & Alb & intraflagellar transport 172 & Ift172, \\
\hline glutathione reductase & $G s r$ & myoglobin & $M b$ \\
\hline $\begin{array}{l}\text { sulfiredoxin } 1 \text { homolog }(\mathrm{S} . \\
\text { cerevisiae })\end{array}$ & Srxn1 & neuroglobin & $N g b$ \\
\hline thioredoxin reductase 1 & Txnrd1 & solute carrier family 38, member 1 & Slc38a1 \\
\hline thioredoxin reductase 2 & Txnrd2 & vimentin & $\operatorname{Vim}$ \\
\hline thioredoxin reductase 3 & Txnrd3 & beta-2 microglobulin & $B 2 m$ \\
\hline $\begin{array}{l}\text { superoxide dismutase } 1, \\
\text { soluble }\end{array}$ & Sod1 & $\begin{array}{l}\text { heat shock protein } 90 \text { alpha (cytosolic), } \\
\text { class B member } 1\end{array}$ & Hsp90ab1 \\
\hline $\begin{array}{l}\text { superoxide dismutase } 3, \\
\text { extracellular }\end{array}$ & Sod3 & actin, beta & $A c t b$ \\
\hline $\begin{array}{l}\text { superoxide dismutase } 2, \\
\text { mitochondrial }\end{array}$ & Sod2 & $\begin{array}{l}\text { glyceraldehyde-3-phosphate dehydro- } \\
\text { genase }\end{array}$ & Gapdh \\
\hline $\begin{array}{l}\text { copper chaperone for su- } \\
\text { peroxide dismutase }\end{array}$ & Ccs & glucuronidase, beta & Gusb \\
\hline $\begin{array}{l}\text { cytochrome b-245, alpha } \\
\text { polypeptide }\end{array}$ & $C y b a$ & mVPA1 & $m V P A 1$ \\
\hline $\begin{array}{l}\text { neutrophil cytosolic factor } \\
1\end{array}$ & $N c f 1$ & & \\
\hline $\begin{array}{l}\text { neutrophil cytosolic factor } \\
2\end{array}$ & $N c f 2$ & & \\
\hline $\begin{array}{l}\text { nitric oxide synthase } 2 \text {, in- } \\
\text { ducible }\end{array}$ & Nos 2 & & \\
\hline NADPH oxidase 1 & Nox1 & & \\
\hline NADPH oxidase 4 & Nox4 & & \\
\hline $\begin{array}{l}\text { NADPH oxidase activator } \\
1\end{array}$ & Noxal & & \\
\hline $\begin{array}{l}\text { NADPH oxidase organizer } \\
1\end{array}$ & Noxol & & \\
\hline RecQ protein-like 4 & Recql4 & & \\
\hline $\begin{array}{l}\text { stearoyl-Coenzyme A de- } \\
\text { saturase } 1\end{array}$ & Scdl & & \\
\hline $\begin{array}{l}\text { uncoupling protein } 2 \text { (mi- } \\
\text { tochondrial, proton car- } \\
\text { rier) }\end{array}$ & $U c p 2$ & & \\
\hline aldehyde oxidase 1 & Aox1 & & \\
\hline $\begin{array}{l}\text { flavin containing } \\
\text { monooxygenase } 2\end{array}$ & Fmo2 & & \\
\hline interleukin 19 & $I l 19$ & & \\
\hline
\end{tabular}


The analyzed genes were selected from http://www.sabiosciences.com database for PCR profiling of different biological processes. The level of gene transcription was normalized by the levels of expression of housekeeping genes $\beta$-actin, B2m (beta-2 microglobulin), Hsp90ab1 (heat shock protein 90 alpha (cytosolic), class B member 1), gapdh (glyceraldehyde-3-phosphate dehydrogenase) and Gusb (glucuronidase, beta). Each measurement was repeated twice (internal repetition) and averaged for 2 independent samples. The obtained expression data were analyzed using http://www.sabiosciences.com online services, mayday-2.14 software (Center for Bioinformatics Tubingen, Germany) and the Genesis software.

\subsection{Statistical analysis}

The experiments were conducted in 3 or 4 repetitions. Experimental results were compared with the control. Statistical analysis was performed using the methods of variation statistics. We determined the mean values and the standard deviation of the mean. The significance of the difference between the groups was determined by Student t-test. The obtained data were processed using GraphPad 6.0 and Microsoft Excel 2007 software.

\section{Results and discussion}

The synthesized $\mathrm{WO}_{3-x}$ sol possesses good photochromic properties - it turns blue under UV radiation, and in the absence of the UV light it gradually becomes colorless. A detailed study of the sol's photochromic properties regeneration showed the changes in the sol's discolouration rate during the repeated UV exposure. Thus, after the first irradiation (cycle 1), the sol become almost completely colorless in 10 min (Fig. 1(a)). In turn, after the fifth and tenth irradiation (cycles 5 and 10, respectively) the sol remained light blue (Fig. 1(b,c)). It is also worth noting that the absorption coefficient of the $\mathrm{WO}_{3-x}$ sol after each irradiation cycle changed. To determine the possible influence of polyvinylpyrrolidone stabilizer, we conducted a control experiment with an individual PVP solution prepared in a similar way. The concentration of the solution was $0.03 \mathrm{~mol} / \mathrm{L}$. Fig. 1(d,e) show that the PVP solution is stable under UV light, irrespective of the number of cycles.

Analysis of the dehydrogenase activity via MTT assay after 24 and 72 hours of incubation with tungsten oxide nanoparticles showed a dose-dependent viability decrease (Fig. 2). In particular, viability of mouse fibroblasts was significantly reduced after 24 hours of culturing with $\mathrm{WO}_{3-x} \mathrm{NPs}(5-15 \mathrm{mg} / \mathrm{ml})$. Analysis of cell viability after 72 hours of culturing also showed a significant decrease in the dehydrogenase activity for all the studied concentrations of $\mathrm{WO}_{3-x}$ nanoparticles $(1-15 \mathrm{mg} / \mathrm{ml})$. Such decrease indicates disturbances in the functioning of mitochondria. Considering the ability of $\mathrm{WO}_{3-x}$ NPs to generate ROS and free radicals [10], we can suggest that oxidative stress in the cell was developed.

Analysis of the proliferative activity of the cells revealed an inhibitory effect of $\mathrm{WO}_{3-x}$ nanoparticles (Fig. 3). Low concentrations of $\mathrm{WO}_{3-x}$ nanoparticles $(1$ and $2.5 \mathrm{mg} / \mathrm{ml}$ ) did not significantly reduce the proliferative activity of the cells (Fig. 3(b)). However, even a $5 \mathrm{mg} / \mathrm{ml}$ concentration of $\mathrm{WO}_{3-x}$ nanoparticles led to a $50 \%$ inhibition of proliferative activity, resulting in the change of cell confluence. Higher concentrations of $\mathrm{WO}_{3-x}$ nanoparticles $(10$ and $15 \mathrm{mg} / \mathrm{ml})$ resulted in more than $70 \%$ inhibition of proliferative activity (Fig. 3(c)). Upon 72 hours incubation with higher concentrations of $\mathrm{WO}_{3-x}$ nanoparticles, the appearance of the cells also changed significantly. After 72 hours, almost all the cells detached from the substrate, acquired a rounded shape, losing the characteristic spreading (Figure 3a).

We analyzed the number of dead cells after incubation with $\mathrm{WO}_{3-x}$ nanoparticles using fluorescent dyes (Syto 9/propidium iodide) (Fig. 4). This analysis did not reveal the presence of dead cells after 24 hours of cultivation with 1 to $10 \mathrm{mg} / \mathrm{ml}$ of $\mathrm{WO}_{3-x}$ nanoparticles. Meanwhile, higher concentration of $\mathrm{WO}_{3-x}$ nanoparticles $(15 \mathrm{mg} / \mathrm{ml})$ led to the appearance of dead cells. After 72 hours of incubation, 5,10 and $15 \mathrm{mg} / \mathrm{ml}$ concentrations of $\mathrm{WO}_{3-x}$ nanoparticles resulted in a significant proportion of dead cells. A significant reduction in the number of the cells indicated both an inhibitory effect on the proliferation of the cell culture and their detachment from the substrate.

We carried out gene expression analysis of the effect of tungsten oxide nanoparticles on cellular components. PCR RT method was used to analyze mRNA expression of 96 genes responsible for the development of oxidative stress response (Fig. 5). The data obtained indicated that $\mathrm{WO}_{3-x}$ nanoparticles led to changes in the transcriptional activity of genes associated with the development and protection against oxidative stress. The action of $\mathrm{WO}_{3-x}$ nanoparticles was found to be dose- and time-dependent. Thus, $\mathrm{WO}_{3-x}$ nanoparticles $(1 \mathrm{mg} / \mathrm{ml})$ after 24 hours incubation activated transcription of the glutathione peroxidase $(G P x)$ genes $(G p x 1-3, G p x 5-7$ and Gstkl) and some other peroxidase genes (Epx, Lpo, Mpo, Rag2, Serpinb1b and Tpo). There was also an increase in the transcriptional activity of a few genes associated with reactive oxygen species (ROS) metabolism (Cyba, Nos2, Nox4, Il22), six genes associated with oxidative stress response (Ercc2, H spala, Krt1, Txn1 and Xpa) and one gene of the oxygen transporters group $(N g b)$. After $72 \mathrm{~h}$, a significant activation of gene expression took place, but with a different pattern. Thus, in the glutathione peroxidases and peroxiredoxins (TPX) cluster, an increased level 

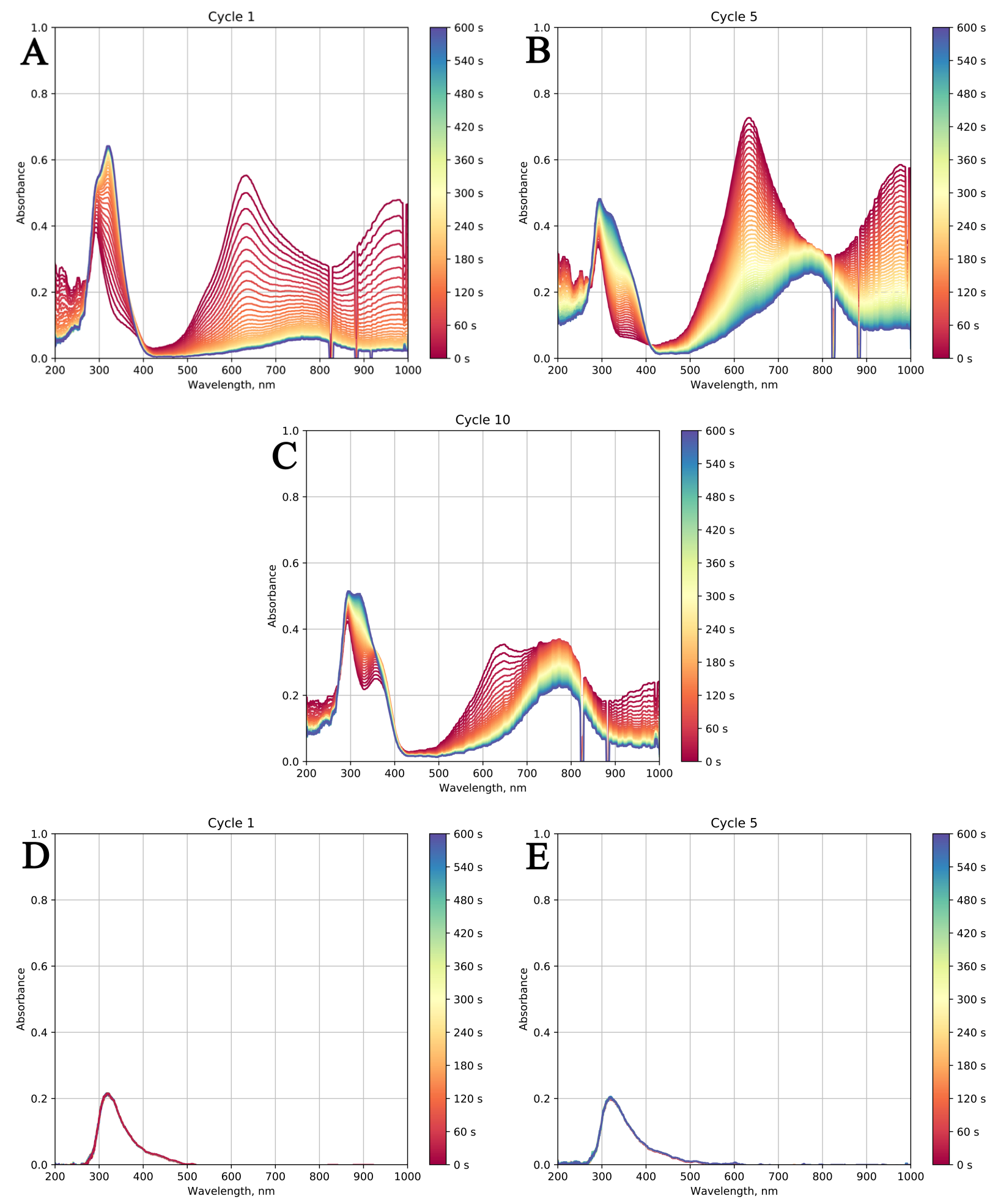

FIG. 1. Absorption spectra of the sol at the first, fifth and tenth irradiation cycle, respectively (A-C), absorption spectra of the PVP solution during the first and fifth cycle (D-E) 


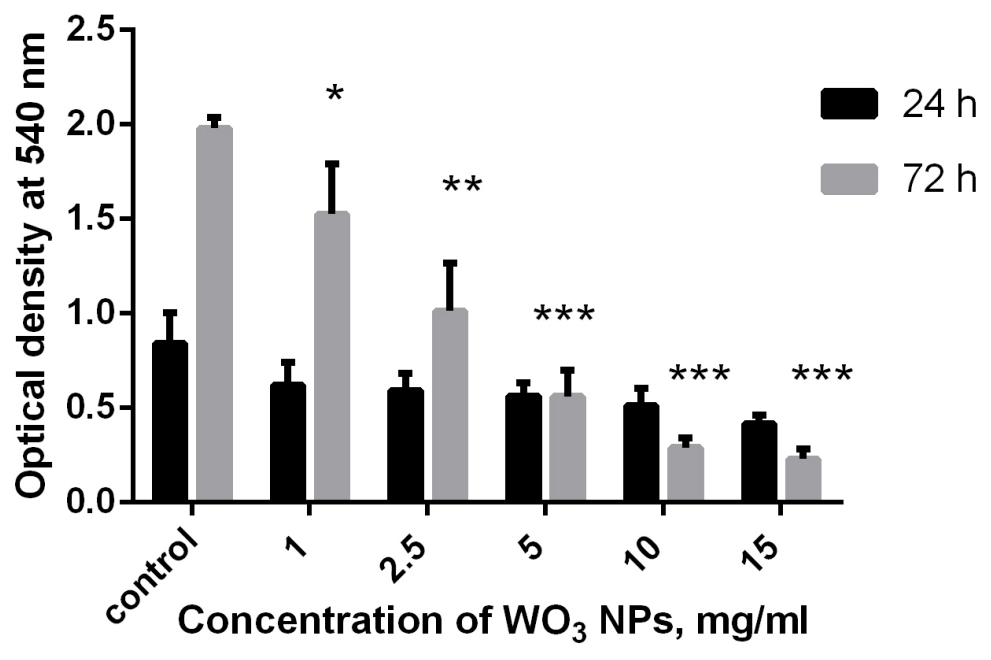

FIG. 2. Results of MTT assay 24 and $72 \mathrm{~h}$ after incubation of NTCT L929 cells with $\mathrm{WO}_{3-x}$ nanoparticles. Data are presented as mean $\pm s d$ ( $y E r \pm), n=3 .{ }^{*}-p \leq 0.05,{ }^{*}-p \leq 0.001$, $* * *-p \leq 0.0001$ according to Mann-Whitney U-test

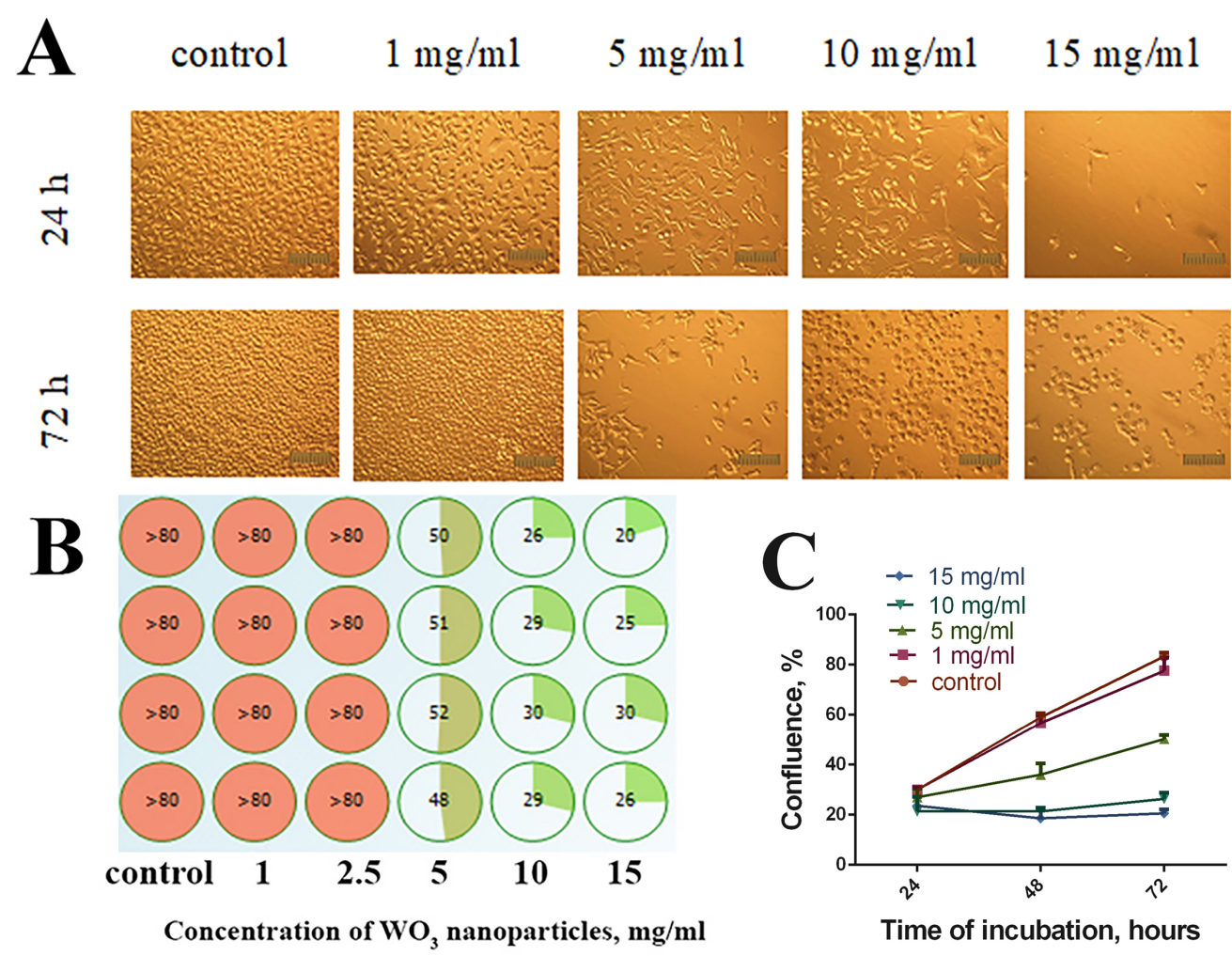

FIG. 3. Microphotographs of NCTC L929 cells after 24 and $72 \mathrm{~h}$ incubation with $\mathrm{WO}_{3-x}$ nanoparticles $(1-15 \mathrm{mg} / \mathrm{ml})(\mathrm{A})$. Confluence of NCTC L929 cells after $72 \mathrm{~h}$ of incubation with $\mathrm{WO}_{3-x}$ nanoparticles $(1-15 \mathrm{mg} / \mathrm{ml})(B)$. Growth curve of NCTC L929 cells after 3 day incubation (C). Cells were plated in 96 well plates and left overnight. Then $\mathrm{WO}_{3-x}$ nanoparticles $(1-15 \mathrm{mg} / \mathrm{ml})$ were added and after 24,48 and $72 \mathrm{~h}$ cells confluence was analyzed 


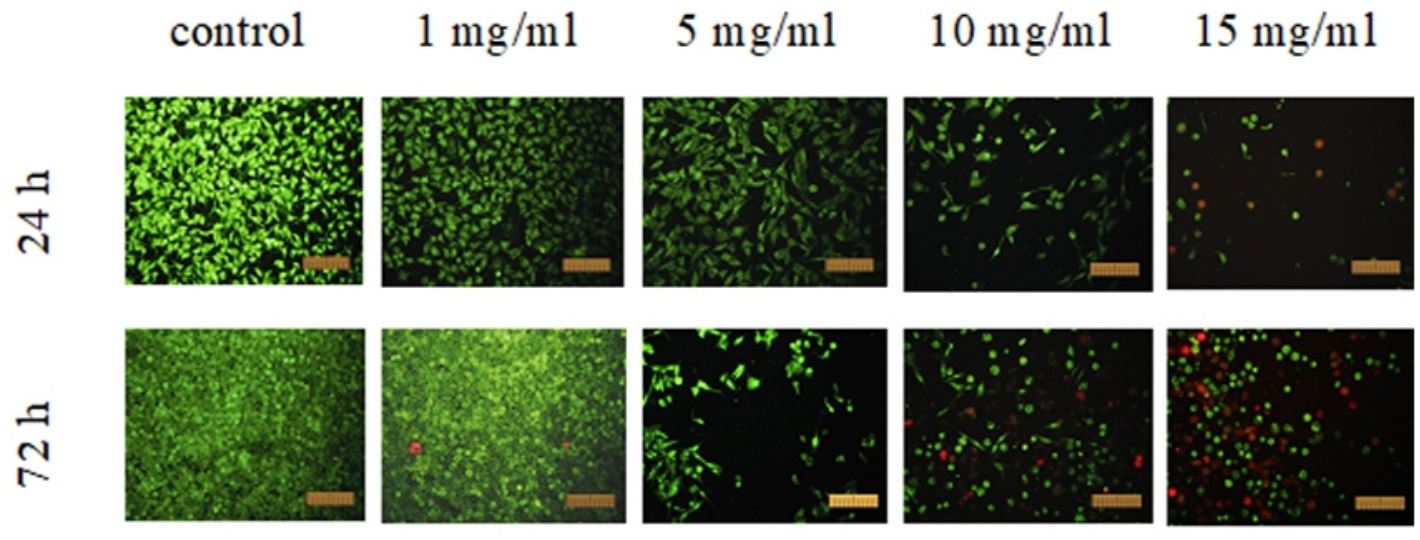

FIG. 4. Microphotographs of NCTC L929 cells after 24 and $72 \mathrm{~h}$ incubation with $\mathrm{WO}_{3-x}$ nanoparticles $(1-15 \mathrm{mg} / \mathrm{ml})$. Cells were plated in 96 well plates and left overnight. Then $\mathrm{WO}_{3-x}$ nanoparticles $(1-15 \mathrm{mg} / \mathrm{ml})$ were added and after 24 and $72 \mathrm{~h}$ cells were stained with L-7007 LIVE/DEAD kit

of transcription of only 3 genes (Gpx2, Gpx3 and Ehd2) was recorded, and the expression level of some genes of this group was reduced compared to the control (Gpx5, Gpx6 and Gstk1). During this period, an increase in the expression of genes of other peroxidases (Apc, Cat, Duox1, Lpo, Ptgs2, Serpinb1b and Tpo) occurred. In contrast to the 24-hour incubation period, after 72 hours incubation, NCTCT L929 cells showed increased transcription of 2 other antioxidant genes ( $A l b$ and Txnrd2), and in the cluster of other superoxide metabolism genes 7 genes were up-regulated - Cyba, Noxl, Noxa1, Recql4, Scd1, Aoxl and Il19.

Compared to $24 \mathrm{~h}$ incubation, an increase in the transcription of a larger number of genes (Als2, Apoe, Ccl5, Ercc6, Ercc2, Gclc, Sqstm1, Txn1, Txnip, and Ucp3) occurred in the oxidative stress responsive genes cluster. In the group of oxygen transporters, there was a total activation of the expression of all genes, except for $\operatorname{Vim}$. $\mathrm{WO}_{3-x}$ nanoparticles at the concentration of $10 \mathrm{mg} / \mathrm{ml}$ led to an increase in the transcriptional activity of genes involved in the development of oxidative stress. Meanwhile, the transcriptional expression patterns were very similar to those recorded for $1 \mathrm{mg} / \mathrm{ml}$ concentration after 72 hours of incubation. At the same time, in some clusters, a significant decrease in the expression of some genes was observed (Gpx2, Gstp1, Ehd2, Prdx1, Prdx2, Prdx3, Cat, Serpinb1b, Gsr, Sod3, Txnrd1, Txnrd3, Noxo1, Scd1, Ucp2, Gclc, Gcl, Im, Txnrd3, Noxo1, Scd1, Ucp2, Gclc, Gcl, Im, Txnrd3, Noxo1, Scd1, Ucp2, Gclc, Gcl. Cygb, Fancc, Vim). After 72 hours of cell incubation with $10 \mathrm{mg} / \mathrm{ml} \mathrm{WO}_{3-x}$ concentration, up-regulation of the maximum number of genes was observed. Thus, in peroxiredoxins group (TPX) and other antioxidants, all studied genes were upregulated, as well as $70 \%$ genes in the oxidative stress responsive cluster. Despite this, expression of some genes was down-regulated (Gpx2, Gpx3, Gpx5, Gpx6 Gstk1, Epx, Mpo, Rag2, Ncf1, Nos2, Noxo1, Fmo2, Hspala, Krt1 and Ngb). This suggests that $\mathrm{WO}_{3-x}$ nanoparticles have a pronounced pro-oxidant activity. Our results showed that $\mathrm{WO}_{3-x}$ nanoparticles are able to significantly modulate both pro- and antioxidant gene expression. Firstly, $\mathrm{WO}_{3-x}$ nanoparticles activated the glutathione peroxidases and peroxiredoxins after $24 \mathrm{~h}$ even at low concentrations $(1 \mathrm{mg} / \mathrm{ml})$. Higher concentration of $\mathrm{WO}_{3-x}$ nanoparticles $(10 \mathrm{mg} / \mathrm{ml})$ led to the activation of the transcriptional activity of other antioxidant protection genes and genes responsible for ROS metabolism.

\section{Conclusions}

PVP-stabilized tungsten oxide nanoparticles provide dose- and time-dependent inhibition of the mouse fibroblasts proliferative activity due to the induction of strong oxidative stress leading to cell death. The intermediate concentration of $\mathrm{WO}_{3-x}$ nanoparticles $(5 \mathrm{mg} / \mathrm{ml})$ showed significant inhibition of proliferation, while higher concentrations $(10$ and $15 \mathrm{mg} / \mathrm{ml})$ resulted in the development of apoptosis and cell death. $\mathrm{WO}_{3-x}$ concentrations less than $2.5 \mathrm{mg} / \mathrm{ml}$ did not cause an increased cell death and did not significantly affect cell metabolism. The obtained data indicate that $\mathrm{WO}_{3-x}$ nanoparticles may have a potential toxic effect on mammalian cells.

\section{Acknowledgements}

This study was funded by Russian Science Foundation (project 18-73-10150). 
A

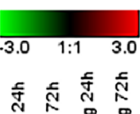

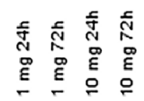

B
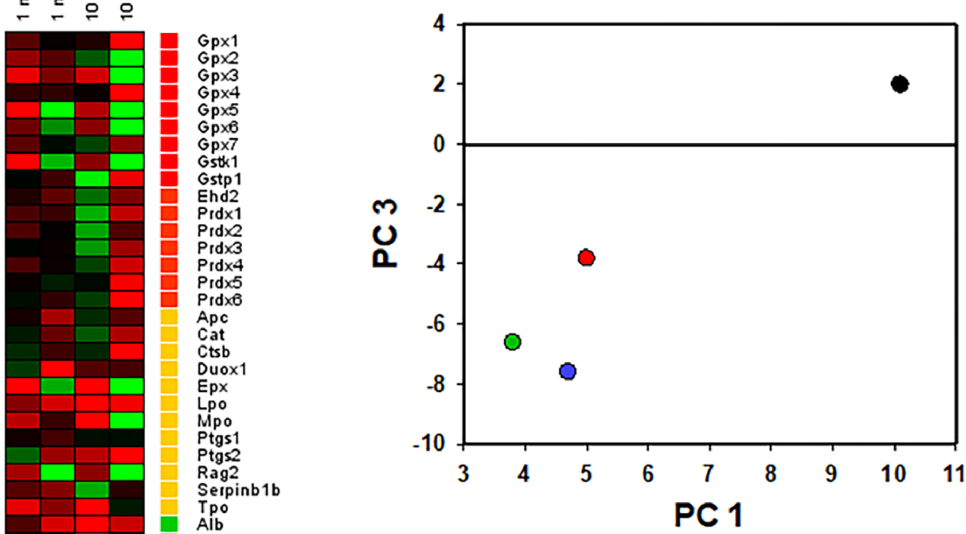

- $1 \mathrm{mg} 24 \mathrm{~h}$

$10 \mathrm{mg} 72 \mathrm{~h}$

- $10 \mathrm{mg} 24 \mathrm{~h}$

$1 \mathrm{mg} 72 \mathrm{~h}$

9

PC 1

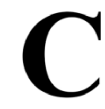

\begin{tabular}{|l|l|}
\hline & Glutathione Peroxidases (GPX) \\
\hline & Peroxiredoxins (TPx): \\
\hline Other Peroxidases \\
\hline & Other Antioxidants) \\
\hline Other Superoxide Metabolism Genes \\
\hline $\begin{array}{l}\text { Other Reactive Oxygen Species } \\
\text { (ROS) Metabolism Genes }\end{array}$ \\
\hline Oxidative Stress Responsive Genes \\
\hline Oxygen Transporters \\
\hline
\end{tabular}

FIG. 5. Heat map of gene expression in NCTC L929 cells treated with $\mathrm{WO}_{3-x}$ nanoparticles ( 1 and $10 \mathrm{mg} / \mathrm{ml}$ ) after 24 and $72 \mathrm{~h}$ of incubation $(\mathrm{A})$. The intensity scale of the standardized expression values ranges from -3 (green: low expression) to +3 (red: high expression, with 1:1 intensity value (black) representing the control (non-treated). Principal component analysis (PCA) of qRT-PCR data from different concentration of $\mathrm{WO}_{3-x}$ nanoparticles (B). Cluster groups of genes and their functionality $(\mathrm{C})$ 


\section{References}

[1] Firouzi M., Poursalehi R., et al. Chitosan coated tungsten trioxide nanoparticles as a contrast agent for X-ray computed tomography. Int. J. Biol. Macromol., 2017, 98, P. 479-485.

[2] Popov A.L., Savintseva I.V., et al. Cytotoxicity analysis of gadolinium doped cerium oxide nanoparticles on human mesenchymal stem cells. Nanosyst. Phys. Chem. Math., 2018, 9 (3), P. 430-438.

[3] Popov A.L., Shcherbakov A.B., et al. Cerium dioxide nanoparticles as third-generation enzymes (Nanozymes). Nanosyst. Phys. Chem. Math., 2017, 8 (6), P. 760-781.

[4] Popova N.R., Popov A.L., Shcherbakov A.B., Ivanov V.K. Layer-by-layer capsules as smart delivery systems of $\mathrm{CeO}_{2}$ nanoparticle-based theranostic agents. Nanosyst. Phys. Chem. Math., 2017, 8 (2), P. 282-289.

[5] Popov A.L., Popova N.R., et al. Cerium oxide nanoparticles stimulate proliferation of primary mouse embryonic fibroblasts in vitro. Mater. Sci. Eng., C, 2016, 68, P. 406-413.

[6] Hosseini F., Rasuli R., Jafarian V. Immobilized WO3 nano-particles on graphene oxide as a photo-induced antibacterial agent against UV resistant Bacillus Pumilus. J. Phys. D: Appl. Phys., 2018, 51 (14), 145403.

[7] Hariharan V., Radhakrishnan S., et al. Synthesis of polyethylene glycol (PEG) assisted tungsten oxide (WO 3 ) nanoparticles for L-dopa bio-sensing applications. Talanta, 2011, 85 (4), P. 2166-2174.

[8] Deng K., Hou Z., et al. Enhanced Antitumor Efficacy by $808 \mathrm{~nm}$ Laser-Induced Synergistic Photothermal and Photodynamic Therapy Based on a Indocyanine-Green-Attached $\mathrm{W}_{18} \mathrm{O}_{49}$ Nanostructure. Adv. Funct. Mater, 2015,25 (47), P. 7280-7290.

[9] Chen Z., Wang Q., et al. Ultrathin PEGylated W18O49 nanowires as a new 980 nm-laser-driven photothermal agent for efficient ablation of cancer cells in vivo. Adv. Mater., 2013, 25 (14), P. 2095-2100.

[10] Sharker S.Md., Kim S.M., et al. Functionalized biocompatible $\mathrm{WO}_{3}$ nanoparticles for triggered and targeted in vitro and in vivo photothermal therapy. J. Control. Release, 2015, 217, P. 211-220.

[11] Zhou Z., Kong B., et al. Tungsten Oxide Nanorods: An Efficient Nanoplatform for Tumor CT Imaging and Photothermal Therapy. Sci. Rep., 2014, 4, 3653.

[12] Liu J., Han J., et al. In vivo near-infrared photothermal therapy and computed tomography imaging of cancer cells using novel tungstenbased theranostic probe. Nanoscale, 2014, 6 (11), P. 5770-5776.

[13] Liu P., Wang Y., et al. Ultrasmall $\mathrm{WO}_{3-x} @ \gamma$-poly-1-glutamic Acid Nanoparticles as a Photoacoustic Imaging and Effective PhotothermalEnhanced Chemodynamic Therapy Agent for Cancer. ACS Appl. Mater. Interfaces, 2018, 10 (45), P. 38833-3884.

[14] AbuMousa R.A., Baig U., et al. Photo-catalytic Killing of HeLa Cancer Cells Using Facile Synthesized Pure and Ag Loaded WO 3 Nanoparticles. Sci. Rep., 2018, 8, 15224.

[15] Popov A., Zholobak N., et al. Photo-induced toxicity of tungsten oxide photochromic nanoparticles. J. Photochem. Photobiol. B, 2018, 178, P. 395-403. 